\title{
Phytochemical composition and health-enhancing properties of Oryza sativa L. leaf tea
}

\author{
Karunrat Sakulnarmrat $^{1 *}$, Abdullah Dalar ${ }^{2}$, Aydin Sukru Bengu ${ }^{3}$ and Izabela Konczak ${ }^{4}$ \\ ${ }^{1}$ Department of Agro-industry, Faculty of Agriculture and Technology, Rajamangala University of Technology Isan, Surin 32000, Thailand \\ ${ }^{2}$ Department of Pharmaceutical Botany, Faculty of Pharmacy, Van Yuzuncu Yil University, Van 65090, Turkey \\ ${ }^{3}$ Department of Medical Services and Techniques, Vocational School of Health Services, University of Bingol, Turkey \\ ${ }^{4}$ Food Science and Technology, School of Chemical Sciences and Engineering, University of New South Wales, Sydney, NSW 2052, Australia
}

\begin{abstract}
Phytochemical composition and potential health-enhancing properties of young organic jasmine rice (Oryza sativa L.) leaf tea, cv. Khao dok mali 105 (KM) and Homnil (HN), were investigated. Sequential extraction using organic solvents (acetone, ethanol, water) revealed that phenolic acids were the dominant compounds of all extracts, with chlorogenic acid being the major contributor. The highest level of total phenolics (113.8 mg GA E/g DW) and antioxidant capacity [FRAP: 1484.2 $\mu \mathrm{mol} \mathrm{Fe} / \mathrm{g}$ DW, DPPH: EC $_{50} 1.31 \mathrm{mg} / \mathrm{mL}$ and ORAC: $4093.1 \mu \mathrm{mol} \mathrm{T} \mathrm{E} / \mathrm{g}$ DW] were identified for KM acetone-based extract. This extract exhibited pronounced $\alpha$-amylase $\left(\mathrm{IC}_{50}=73.96 \pm 2.7 \mu \mathrm{g} / \mathrm{mL}\right)$ and pancreatic lipase $\left(\mathrm{IC}_{50}=65.7 \pm 5.8 \mu \mathrm{g} / \mathrm{mL}\right)$ inhibitory activities. Both rice leaf teas contained volatiles (tridecane, caryophyllene, and dihydroactiniolide) responsible for their attractive and unique aroma. This study suggests that young organic leaf of jasmine rice can be utilized for the production of a novel herbal tea that promotes good health (Figure 1).
\end{abstract}

\section{Introduction}

Herbal teas are a rich source of plant-derived phytochemicals that contribute towards lowering the incidences of chronic diseases [1]. Green tea leaf (Camelia sinensis (L.) Kuntze) is the classic example of a plant-based beverage that, due to its health properties, become extensively utilized in nutraceutical and functional foods industries [2]. Catechins - the dominant phenolic compounds of green tea, are responsible for its distinctive sensory [2] and health promoting properties, including antioxidant and antimicrobial [3], alleviation of clinical features of metabolic syndrome, memory disorders [4], reduction of pathological angiogenesis [5] and cancer prevention [6].

Locally grown botanicals are utilized for the production of herbal teas that display comparable antioxidant capacities to C. sinensis leaf tea [7]. In agreement, herbal teas obtained from rooibos, rosemary, lemongrass, mulberry, bamboo, lotus, peppermint, persimmon and mate are rich sources of antioxidant and antimicrobial compounds [3]. Among numerous water lily cultivars, the 'Conqueror' and 'Virginia' produced teas with an outstanding fragrance, the highest total polyphenols content and superior antioxidant capacities [8].

Recently the Thai government initiated the "One District One Product" program. This initiative represents an important strategy to support local communities through the promotion of their products and sustainable utilization of the local flora. Under this program new plant sources for production of functional tea are evaluated. Rice (Oryza sativa L.) is the staple food crop of Thailand [9] with the largest areas of rice cultivation being the central plains and Northeastern Region [10]. Due to a high market demand for jasmine rice its cultivation in Northeastern Region is growing. The unique scent of jasmine rice can be captured in young leaf tea. The present project aimed at the development of a functional tea obtained from young jasmine rice leaf characterized by unique sensory and health-promoting properties.

\section{Materials and methods}

\section{Plant materials}

Seeds of two Jasmine rice cultivars, white long grain Khao dok mali 105 (KM) and black long grain Homnil (HN) purchased at organic market (Surin province, Thailand) were soaked overnight in water and placed in trays $(40 \times 50 \times 15 \mathrm{~cm})$ containing soil mixture. They were kept at room temperature under daylight and watered every second day. On the $10^{\text {th }}$ day the leaves were collected, washed in MilliQ water and cut into $3 \mathrm{~cm}$ long segments that were air-dried in the dark (room temperature). Subsequently they were roasted at $70^{\circ} \mathrm{C}$, placed in aluminum foiled plastic bags and kept at room temperature until analysis ( $<2$ months). These samples represented herbal teas obtained from the respective rice cultivars. Commercially available green tea (GT; Fujian Lung Ching green tea, China Imex) was included as a reference sample.

\section{Chemicals}

All solvents and chemicals used were of analytical grade. Chlorogenic acid, 2',7'-dichlorofluorescin diacetate (DCFH), D-(+) glucose solution (45\%), 4-(dimetilamino) cinnamaldehyde (DMAC), acetic acid, aluminium chloride hexahydride $\left(\mathrm{AlCl}_{3} \cdot 6 \mathrm{H}_{2} \mathrm{O}\right)$ and Folin-

${ }^{\star}$ Correspondence to: Karunrat Sakulnarmrat, Department of Agro-industry, Faculty of Agriculture and Technology, Rajamangala University of Technology Isan, Surin 32000, Thailand, Tel: 6644153093; Fax: 6644153093; E-mail: karunrat.sa@rmuti.ac.th

Key words: functional drink, jasmine rice tea, polyphenols, volatiles, $\alpha$-amylase, pancreatic lipase, antioxidant activity

Received: October 09, 2018; Accepted: October 31, 2018; Published: November 05,2018 
Ciocalteu reagent were obtained from Merck (Darmstadt, Germany) and 2,4,6-Tri (2-pyridyl)-s-triazine (TPTZ) was obtained from Fluka (Madrid, Spain). Hydrochloric acid ( $\mathrm{HCl}),(+)$-catechin hydrate, iron chloride $\left(\mathrm{FeCl}_{3}\right)$, iron sulphate $\left(\mathrm{FeSO}_{4}\right)$, ethanol, methanol, sodium hydroxide $(\mathrm{NaOH})$ and sodium nitrite $\left(\mathrm{NaNO}_{3}\right)$ were purchased from $\mathrm{QReC}$ (New Zealand). Acetone, 2,2'-azobis (2-amidinopropane $(\mathrm{AAPH}), \mathrm{DPPH}$, intestinal acetone powders from rat, sucrose, formic acid, maleic acid, 4-methylumbelliferyl oleate, porcine pancreatic lipase (Sigma type II), trifluoroacetic acid and fluorescein $(120 \mathrm{nM})$ were obtained from Sigma-Aldrich Inc. (Darmstadt, Germany). Acarbose was obtained from Glucobay (Bayer Healthcare Pharmaceutical, Leverkusen, Germany).

\section{Preparation of lyophilized extract of rice leaf tea}

Lyophilized extracts of teas (KM, HN, GT) were prepared according to Dalar and collaborators [11]. Briefly, tea samples were ground, mixed with a 20 -fold volume of acidified acetone ( $80 \%$ acetone, $19 \%$ MilliQ water and $1 \%$ of $0.1 \%$ trifluoroacetic acid, $\mathrm{v} / \mathrm{v} / \mathrm{v})$, shaken for $2 \mathrm{~h}$ at room temperature and centrifuged for $20 \mathrm{~min}$ at $10,000 \mathrm{rpm}$ and $4^{\circ} \mathrm{C}$ (Centurion, K2R, Centurion Scientific, UK) with supernatant collected. Next, the pellet was extracted using acidified ethanol (80\% ethanol, 19\% MilliQ water and $1 \%$ of $0.1 \%$ trifluoroacetic acid, v/v/v) and then MilliQ water (Synergy, Ultrapure Type I, Merck, France) with supernatants collected each time. The supernatants obtained from three organic solvents extractions were evaporated individually under reduced pressure at $37^{\circ} \mathrm{C}$ using a rotary evaporator (Model N-1N, Eyela, Tokyo Rikakikai, Chuo-ku, Tokyo, Japan). The derived concentrated extracts were dissolved in a minimum amount of MilliQ water, pre-freezed (Eyela PFR1000, Tokyo Rikakikai, Chuo-ku, Tokyo, Japan) and freezedried (Eyela FDU2100, Tokyo Rikakikai, Chuo-ku, Tokyo, Japan) under a vacuum at $-51^{\circ} \mathrm{C}$ to obtain fine lyophilized powders.

\section{Antioxidant capacity}

Total phenolic content (Folin - Ciocalteu assay) and ferric reducing antioxidant power (FRAP) assay: The levels of total phenolics (TP) and total reducing capacities of extracts were assayed as described previously [12].

Free radical scavenging activity (DPPH assay): Free radical scavenging activity was assayed using the 2,2-diphenyl-1-picrylhydrazyl

(DPPH) method according to Sharma and Bhat [13]. Briefly, lyophilized tea extracts were dissolved in $80 \%$ acetone (concentration range 0.01 to $10.0 \mathrm{mg} / \mathrm{mL}$ ) and $0.06 \mathrm{mM}$ of $\mathrm{DPPH}$ was dissolved in $100 \%$ methanol. The DPPH radical solution in methanol $(3.5 \mathrm{~mL}, 0.06$ $\mathrm{mM}$ ) was mixed well with $100 \mu \mathrm{L}$ of tea extract solutions. The mixture was then incubated for $30 \mathrm{~min}$ in the dark at room temperature. The absorbance was measured at $517 \mathrm{~nm}$ using a spectrophotometer (Libra S22, Holliston, MA, USA). The half effective concentration required for $50 \%$ decrease in absorbance of DPPH radicals $\left(\mathrm{EC}_{50}\right)$ was calculated and expressed as mg DW of lyophilized tea extract per $\mathrm{mL}$ of the solution $(\mathrm{mg} / \mathrm{mL})$.

Oxygen radical scavenging capacity (ORAC) assay: The ORAC assay was performed as previously described [11]. The antioxidant capacity of the samples was expressed as $\mu \mathrm{mol}$ trolox equivalent per gram of dry weight of lyophilized extract ( $\mu \mathrm{mol} \mathrm{TE} / \mathrm{g} \mathrm{DW})$ based on a trolox standard curve.

\section{Sugar determination}

Reducing sugars and total sugars were measured as reported by AOAC [14]. All results were expressed as mg of glucose equivalent per gram dry weight (mg G E/g DW) of lyophilized extract.

\section{Identification and quantification of phenolic compounds}

Identification of phenolic compounds byliquid chromatographydiode array-mass spectrometry (LC-DAD-MS/MS): Phenolic compounds were identified with the help of a Quantum triple stage quadrupole (TSQ) mass spectrometer (Thermo Fisher Scientific, Waltham, MA, USA) as described by Dalar and Konczak [15] with the exception that the gradient elution was modified as follows: $0 \%$ solvent B for $2 \mathrm{~min}$, then $40 \%$ B for $6 \mathrm{~min}$, following $60 \%$ of B for $8 \mathrm{~min}$ and $100 \% \mathrm{~B}$ for $4 \mathrm{~min}$.

Quantification of phenolic compounds by high performance liquid chromatography-diode array detector (HPLC-DAD): Phenolic compounds were quantified according to Dalar and Konczak [16]. A modified linear gradient elution was applied of solvent B from 0 to $20 \%$ over $3 \mathrm{~min}$, to $40 \%$ over $5 \mathrm{~min}$, to $60 \%$ over $5 \mathrm{~min}$, to $100 \%$ over $5 \mathrm{~min}$ and the elution was held at the rate of $100 \% \mathrm{~B}$ for another $5 \mathrm{~min}$.

\section{Identification of volatile compounds}

Head space solid phase microextraction (HS-SPME) procedure: Two grams of lyophilized plant extracts were weighed into $40 \mathrm{~mL}$ vials to undergo a solid-phase microextraction (SPME) procedure. The procedure was carried out using divinyl benzene/ carboxen/polydimethylsiloxane fiber, with $50 / 30 \mathrm{~mL}$ film thickness, preconditioned before analysis. The vials were equipped with "mininert" valves and kept at $35^{\circ} \mathrm{C}$ with permanent internal stirring. The samples were left to equilibrate for $30 \mathrm{~min}$. Next, the SPME fiber was placed in the headspace for $40 \mathrm{~min}$. Then the fiber was introduced into GC injector and left for $3 \mathrm{~min}$ to thermal desorption to increase the volatility of compounds. The microextraction procedure was optimized according to Verzera and collaborators [17].

\section{Gas chromatography mass spectrometry (GC-MS) analysis}

The analysis was carried out by gas chromatography mass spectroscopy as described by Dool and Kratz [18]. Fatty acids and volatile compounds were analyzed on Varian 3800 gas chromatograph as described by Uzun and collaborators [19].

\section{Enzyme inhibitory activities}

Alpha-amylase inhibitory activity: Inhibition of $\alpha$-amylase was conducted using the Caraway- Somogyi iodine/potassium iodide (IKI) method as described by Dalar and collaborators [11]. The $\alpha$-amylase inhibitory activity was expressed as micromoles of acarbose equivalents per gram dry weight of lyophilized extract ( $\mu \mathrm{M} \mathrm{A} \mathrm{E/g} \mathrm{DW).}$

Lipase inhibitory activity: The lipase inhibitory activity assay was performed according to Dalar and collaborators [11] using 4-methylumbelliferyl oleate $(0.1 \mathrm{mM})$ as a substrate. The lipase inhibition was reported in micromoles of orlistate equivalents $(\mu \mathrm{M}$ olistate E/g DW of lyophilized tea extract).

\section{Statistical analysis}

The mean of results and standard deviations (SD) were calculated based on at least three independent evaluations $(n=3)$. The half effective concentration $\left(\mathrm{EC}_{50}\right)$ value was calculated from the corresponding dose inhibition curve according to their best fit shapes based on at least four reaction points using Microsoft Excel. Statistical correlation analyses were performed using Graphpad Prism 5 (Graphpad Software, CA, USA). 


\section{Results and discussion}

\section{Yield, sugar content and antioxidant capacities of lyophilized tea extracts}

Samples of dry tea (KM, HN and GT) were extracted sequentially using solvents with increasing polarity level: 1) acidified acetone, 2) acidified ethanol and 3) acidified MilliQ water. This approach has been suggested to achieve the maximum recovery of phytochemicals and good compounds differentiation during extraction from unknown plant sources [20].

The highest product yield (28.9\%) was recorded for GT acetonebased extract (Table 1). The yields of water-based extracts obtained from $\mathrm{KM}$ and $\mathrm{HN}$ rice leaf teas were 2.5- to 2.0-fold that of GT water extract yield indicating comparatively higher levels of polar compounds in rice teas. All three extracts of KM rice tea contained the highest level of total sugar for each category of extract (acetone-, ethanol, or water-based) and were followed by GT extracts. The lowest total sugars contained water- and acetone-based $\mathrm{HN}$ tea extracts (Table 1). The water-based GT extract and ethanol- and acetone-based KM extracts contained the highest level of reducing sugars for each extract category (Table 1). These levels of reducing sugars are comparable or higher than those of Eryngium bornmuelleri leaf tea extracts (acetone-based extract: 71.1 $\pm 0.6 \mathrm{mg} \mathrm{G} \mathrm{E} / \mathrm{g} \mathrm{DW}$, ethanol-based: $49.0 \pm 0.9 \mathrm{mg} \mathrm{G} \mathrm{E} / \mathrm{g} \mathrm{DW}$, waterbased: $37.0 \pm 1.1 \mathrm{mg} \mathrm{G} \mathrm{E} / \mathrm{g}$ DW [11].

The antioxidant potential of sequential leaf tea extracts was evaluated using four reagent-based assays, including total phenolics (TP, Folin-Ciocalteu method), 1,1-diphenyl-2-picrylhydrazyl (DPPH•) free radical assay, total reducing capacity (ferric reducing capacity power, FRAP) and oxygen radical absorbance capacity (ORAC).

The highest levels of total phenolics were found in acetone-based extracts of all teas (Table 1). These levels were approximately 3 -times higher than those of the respective ethanol-based extracts. The least amount of phenolic compounds contained water-based extracts, with the exception of KM. In summary, the highest TP contained green tea, followed by KM and HN tea (Table 1).

The DPPH free radical assay allows to measure the amount of lyophilized extract required to obtain 50\% decrease in absorbance of DPPH free radicals in reaction solution (expressed as $\mathrm{EC}_{50}$ ). The highest DPPH radical scavenging capacity exhibited the acetone-based extracts of all teas (Table 1). This result correlates well with the highest levels of total phenolic compounds detected in the same extracts (Table 1). The lowest DPPH radical scavenging ability within their extract category exhibited HM-acetone-, KM ethanol- and KM water-based extract. The HN acetone-based and ethanol-based extracts had comparable DPPH free radical scavenging ability and were slightly more potent than HN water extract (Table 1). Similar tendency was observed for the FRAP and ORAC values; among all the extracts acetone-based exhibited the highest values and were followed by ethanol- and waterbased extracts (Table 1). Superior FRAP and ORAC values in each category of extracts were obtained for green tea (Table 1). Among the acetone-based extracts KM performed better than $\mathrm{HN}$, however among the water-based extracts opposite result was observed (Table 1). Both acetone-based jasmine rice leaf tea extracts (KM and $\mathrm{HN})$ and the reference sample of green tea (GT) exhibited higher ORAC and FRAP values than those of Eryngium bornmuelleri leaf tea extracts obtained through the same extraction process. However, the ORAC and FRAP values of the ethanol- and water-based extracts evaluated in this study were comparable to those of the respective ethanol- and water-based Eryngium bornmuelleri leaf tea extracts [11]. These results suggest that with regards to antioxidant capacity jasmine rice leaf teas are inferior to green tea, and they are comparable or superior to other traditionally utilized ethnic teas prepared from locally grown botanicals.

\section{Identification and quantification of phenolic compounds present in tea extracts}

Identification of phenolic compounds in sequential extracts obtained from rice leaf tea was carried out by high performance liquid chromatography (HPLC) and liquid chromatography mass spectrometry (LC-MS) analyses (Table 2). The HPLC profiles of acetone- and ethanol-based extracts of both jasmine rice leaf teas were very similar with the exception that the concentration of phenolic compounds in acetone-based extract was higher (Figures 2 and 3). The majority of compounds present in $\mathrm{KM}$ and $\mathrm{HN}$ teas were visible on HPLC chromatogram at $326 \mathrm{~nm}$ wavelength (Figure 2). The spectral characteristics of HPLC peaks revealed that chlorogenic acids (4and 5-chlorogenic acid) are the dominating phenolic compounds of both jasmine rice teas. The majority of compounds present in green tea extracts were found at $280 \mathrm{~nm}$ with gallic acid, catechin and epigallocatechin identified (Figure $3 \mathrm{C}$ ). Gallic acid was also the dominating phenolic compound in KM water extract (Figure 4A)

Table 1. Extraction yield, reducing and total sugars, total phenolics, and antioxidant capacity of lyophilized fractions obtained from jasmine rice young leaf tea, cultivars Khao Dok Mali 105 and Homnil, and reference sample green tea

\begin{tabular}{|c|c|c|c|c|c|c|c|c|}
\hline $\begin{array}{l}\text { Extraction } \\
\text { solvent }\end{array}$ & $\begin{array}{c}\text { Tea } \\
\text { Sample }\end{array}$ & $\begin{array}{l}\text { Yield } \\
(\%)\end{array}$ & $\begin{array}{l}\text { Reducing sugar } \\
(\mathrm{mg} \mathrm{G} \mathrm{E/g} \mathrm{DW)}\end{array}$ & $\begin{array}{c}\text { Total Sugar } \\
(\mathrm{mg} \mathrm{G} \mathrm{E} / \mathrm{g} \mathrm{DW})^{\mathrm{a}}\end{array}$ & $\begin{array}{c}\text { TP } \\
(\mathrm{mg} \mathrm{GA} \mathrm{E} / \mathrm{g} \mathrm{DW})^{\mathrm{b}}\end{array}$ & $\begin{array}{c}\mathrm{DPPH} \\
\left(\mathrm{EC}_{50} ; \mathrm{mg} / \mathrm{mL}\right)\end{array}$ & $\begin{array}{c}\text { FRAP } \\
(\mu \mathrm{mol} \mathrm{Fe}+2 / g \text { DW })\end{array}$ & $\begin{array}{c}\text { ORAC } \\
(\mu \mathrm{mol} \mathrm{TE} / \mathrm{g} \mathrm{DW})\end{array}$ \\
\hline \multicolumn{9}{|c|}{ Acetone (A) } \\
\hline & $\mathrm{KM}$ & 6.0 & $58.8 \pm 1.8^{\mathrm{a}}$ & $112.5 \pm 1.6^{\mathrm{a}}$ & $113.8 \pm 2.7^{b}$ & $1.31^{\mathrm{b}}$ & $1484.2 \pm 43.4^{b}$ & $4093.1 \pm 177.0^{\mathrm{b}}$ \\
\hline & $\mathrm{HN}$ & 3.6 & $12.01 \pm 1.2^{\mathrm{b}}$ & $32.2 \pm 2.1^{\mathrm{c}}$ & $107.5 \pm 5.5^{\mathrm{c}}$ & $3.67^{\mathrm{a}}$ & $1285.9 \pm 50.2^{\mathrm{c}}$ & $3452.8 \pm 146.4^{c}$ \\
\hline & GT & 28.9 & $4.8 \pm 0.3^{\mathrm{c}}$ & $87.2 \pm 0.7^{\mathrm{b}}$ & $346.7 \pm 5.1^{\mathrm{a}}$ & $1.25^{\mathrm{c}}$ & $9596.4 \pm 70.5^{\mathrm{a}}$ & $5115.1 \pm 170.7^{\mathrm{a}}$ \\
\hline \multicolumn{9}{|c|}{ Ethanol (E) } \\
\hline & KM & 5.1 & $61.6 \pm 5.8^{\mathrm{a}}$ & $125.3 \pm 2.8^{\mathrm{a}}$ & $31.3 \pm 1.0^{\mathrm{b}}$ & $6.41^{\mathrm{a}}$ & $747.8 \pm 41.4^{\mathrm{b}}$ & $2320.8 \pm 123.5^{c}$ \\
\hline & $\mathrm{HN}$ & 2.3 & $42.0 \pm 2.1^{\mathrm{c}}$ & $98.4 \pm 1.4^{\mathrm{b}}$ & $28.9 \pm 1.6^{c}$ & $3.79^{\mathrm{c}}$ & $543.8 \pm 32.0^{c}$ & $2906.0 \pm 76.9^{b}$ \\
\hline & GT & 6.4 & $44.6 \pm 1.8^{\mathrm{b}}$ & $92.1 \pm 2.1^{\mathrm{c}}$ & $142.7 \pm 2.2^{\mathrm{a}}$ & $4.73^{b}$ & $4577.3 \pm 61.4^{\mathrm{a}}$ & $3981.0 \pm 79.5^{\mathrm{a}}$ \\
\hline \multicolumn{9}{|c|}{ Water $(W)$} \\
\hline & KM & 7.6 & $65.2 \pm 2.6^{\mathrm{b}}$ & $128.2 \pm 1.6^{\mathrm{a}}$ & $36.6 \pm 1.6^{\mathrm{a}}$ & $4.76^{\mathrm{a}}$ & $215.3 \pm 13.1^{\mathrm{c}}$ & $1762.1 \pm 68.5^{\mathrm{c}}$ \\
\hline & $\mathrm{HN}$ & 6.3 & $6.24 \pm 2.1^{\mathrm{c}}$ & $77.5 \pm 2.8^{c}$ & $16.4 \pm 1.1^{\mathrm{c}}$ & $4.52^{\mathrm{b}}$ & $441.9 \pm 13.1^{\mathrm{b}}$ & $1784.2 \pm 41.0^{\mathrm{b}}$ \\
\hline & GT & 3.0 & $71.0 \pm 1.3^{\mathrm{a}}$ & $105.3 \pm 3.0^{\mathrm{b}}$ & $32.8 \pm 2.2^{\mathrm{b}}$ & $3.57^{\mathrm{c}}$ & $685.5 \pm 21.7^{\mathrm{a}}$ & $2024.9 \pm 72.0^{\mathrm{a}}$ \\
\hline
\end{tabular}

Data represents the mean \pm standard deviation of at least three independent experiments. For each parameter investigated values with no letters in common are significantly different at $p<0.05$. a: mg GE/gDW; milligram glucose equivalent per gram dry weight; ${ }^{\text {b: }}$ mg GA E/gDW milligram gallic acid equivalent per gram dry weight; FRAP: Ferric reducing antioxidant

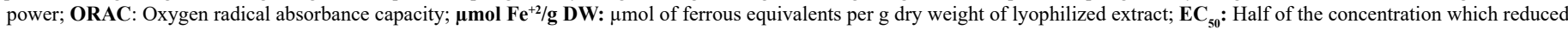
a response halfway; KM: Jasmine rice Khao Dok Mali 105; HN: Jasmine rice Homnil; GT: Green tea 


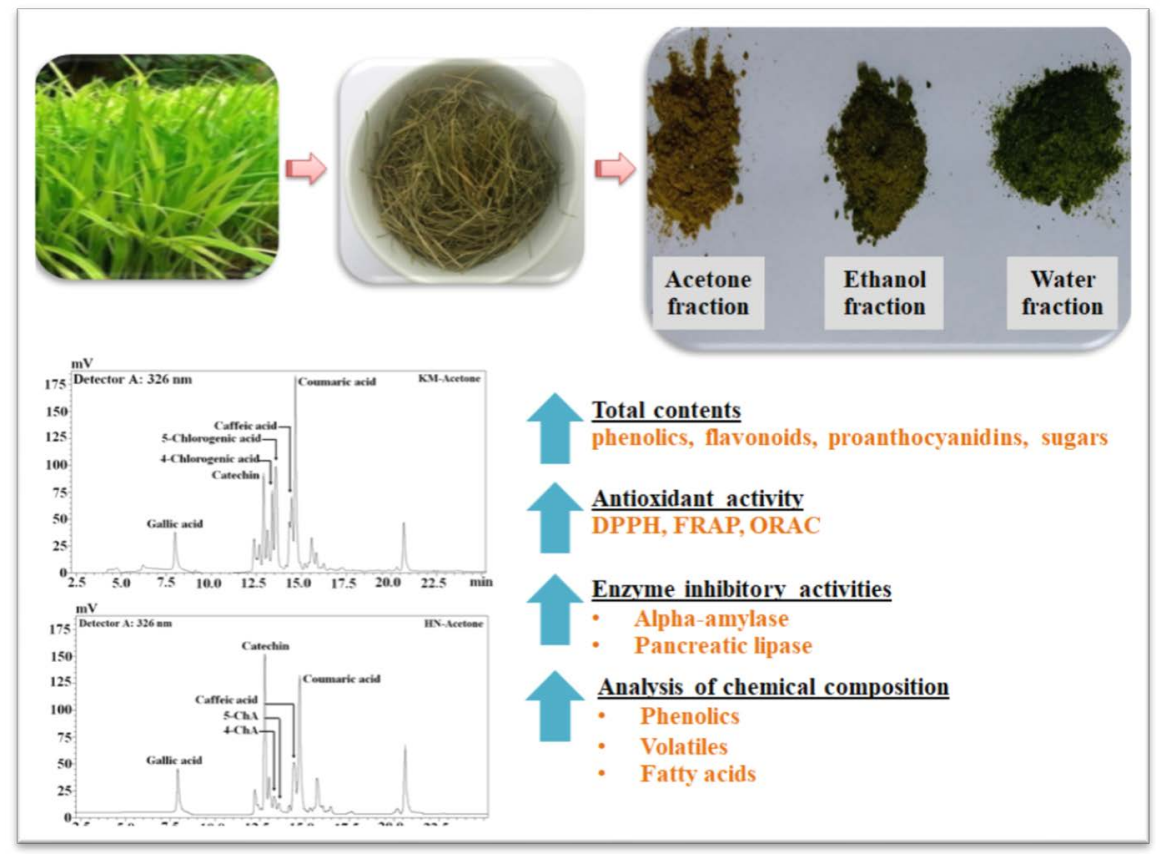

Figure 1. Graphical abstract

Table 2. Phenolic compounds identified in jasmine rice young leaf tea, cultivars Khao Dok Mali 105 and Homnil, and reference sample green tea

\begin{tabular}{|c|c|c|c|c|c|}
\hline \multirow[b]{2}{*}{ Phenolic compound } & \multicolumn{2}{|c|}{ MS/MS } & \multicolumn{3}{|c|}{ Concentration (mg/g extract) } \\
\hline & {$[\mathbf{M}+1]^{+} /[\mathbf{M}-1]^{-}$} & $\begin{array}{c}\text { Fragments } \\
(\mathbf{m} / \mathbf{z})(+/-)\end{array}$ & Acetone & Ethanol & Water \\
\hline \multicolumn{6}{|l|}{$\mathrm{KM}$} \\
\hline$p$-Coumaric acid & $-/ 163$ & $-/ 119$ & $52 \pm 4.2$ & $11.2 \pm 0.6$ & $\mathrm{~T}$ \\
\hline Gallic acid & $-/ 169$ & $-/ 125$ & $7.2 \pm 0.1^{\mathrm{c}}$ & $13.0 \pm 0.6^{\mathrm{b}}$ & $32.1 \pm 1.4^{\mathrm{a}}$ \\
\hline Caffeic acid & $-/ 179$ & $-/ 135$ & $19.2 \pm 1.8^{\mathrm{a}}$ & $9.6 \pm 0.2^{\mathrm{b}}$ & ND \\
\hline Catechin & $-/ 289$ & $-/ 245$ & $17.1 \pm 0.5^{\mathrm{a}}$ & $4.4 \pm 0.0^{\mathrm{b}}$ & $\mathrm{T}$ \\
\hline Epigallocatechin & $-/ 305$ & $-/ 225$ & ND & ND & ND \\
\hline Chlorogenic acid & $-/ 353$ & $-/ 191$ & $54.7 \pm 6.4^{\mathrm{a}}$ & $25.3 \pm 1.1^{\mathrm{b}}$ & $\mathrm{T}$ \\
\hline \multicolumn{6}{|l|}{$\mathrm{HN}$} \\
\hline$p$-Coumaric acid & $-/ 163$ & $-/ 119$ & $36.8 \pm 2.5^{\mathrm{a}}$ & $16.3 \pm 0.9^{b}$ & $3.3 \pm 0.0^{\mathrm{c}}$ \\
\hline Gallic acid & $-/ 169$ & $-/ 125$ & $8.1 \pm 0.4^{b}$ & $12.6 \pm 0.0^{\mathrm{a}}$ & $13.8 \pm 0.4^{\mathrm{a}}$ \\
\hline Caffeic acid & $-/ 179$ & $-/ 135$ & $15.1 \pm 0.6^{\mathrm{a}}$ & $12.6 \pm 1.0^{\mathrm{b}}$ & $4.2 \pm 0.2^{\mathrm{c}}$ \\
\hline Catechin & $-/ 289$ & $-/ 245$ & $28.4 \pm 1.6^{\mathrm{a}}$ & $3.6 \pm 0.1^{\mathrm{b}}$ & $1.6 \pm 0.0^{\mathrm{c}}$ \\
\hline Epigallocatechin & $-/ 305$ & $-/ 225$ & ND & ND & ND \\
\hline Chlorogenic acid & $-/ 353$ & $-/ 191$ & $8.2 \pm 0.4^{\mathrm{c}}$ & $65.3 \pm 1.7^{\mathrm{a}}$ & $26.6 \pm 1.8^{\mathrm{b}}$ \\
\hline \multicolumn{6}{|l|}{ GT } \\
\hline$p$-Coumaric acid & $-/ 163$ & $-/ 119$ & ND & ND & ND \\
\hline Gallic acid & $-/ 169$ & $-/ 125$ & ND & $20.1 \pm 0.9$ & $24.6 \pm 1.2$ \\
\hline Caffeic acid & $-/ 179$ & $-/ 135$ & ND & ND & ND \\
\hline Catechin & $-/ 289$ & $-/ 245$ & $32.5 \pm 1.4^{b}$ & $55.4 \pm 3.8^{\mathrm{a}}$ & $8.0 \pm 0.0^{c}$ \\
\hline Epigallocatechin & $-/ 305$ & $-/ 225$ & $52.5 \pm 3.9^{b}$ & $98.2 \pm 6.5^{\mathrm{a}}$ & $\mathrm{T}$ \\
\hline Chlorogenic acid & $-/ 353$ & $-/ 191$ & ND & ND & ND \\
\hline
\end{tabular}

T: Traces; ND: not detected; KM: Jasmine rice Khao Dok Mali 105; HN: Jasmine rice Homnil; GT: green tea

while chlorogenic acid was the dominating compound in $\mathrm{HN}$ water extract (Figure 4B). In agreement with the HPLC chromatograms the mass spectroscopy data confirmed that hydroxycinnamic acids were the major phenolic compounds identified in both jasmine rice leaf teas (Table 2). Chlorogenic acid and $p$-coumaric acid were the major phenolic compounds of KM acetone and ethanol extracts representing, respectively, $36 \%$ and $34 \%$ of total phenolics (Table 2). Chlorogenic acid identified in $\mathrm{HN}$ ethanol and water extracts accounted for, respectively, $59 \%$ and $54 \%$ of total phenolics. Significant amounts of gallic acid and catechin were also detected (Table 2). The dominating compounds of GT extracts were catechin and epigallocatechin gallate (Figures 2-4). Dai and Mumper [20] reported that ethanol is an efficient extraction solvent of low molecular weight polyphenols, while aqueous acetone is more suitable for the extraction of high molecular weight flavanols. This study identified similar phenolic composition of both, ethanol and acetone jasmine rice leaf tea extracts (Table 2). These results suggest that in the evaluated jasmine rice leaf teas high molecular weight compounds are present at very low levels or are absent. Similar results were reported for Eryngium bornmuelleri leaf tea [11]. 


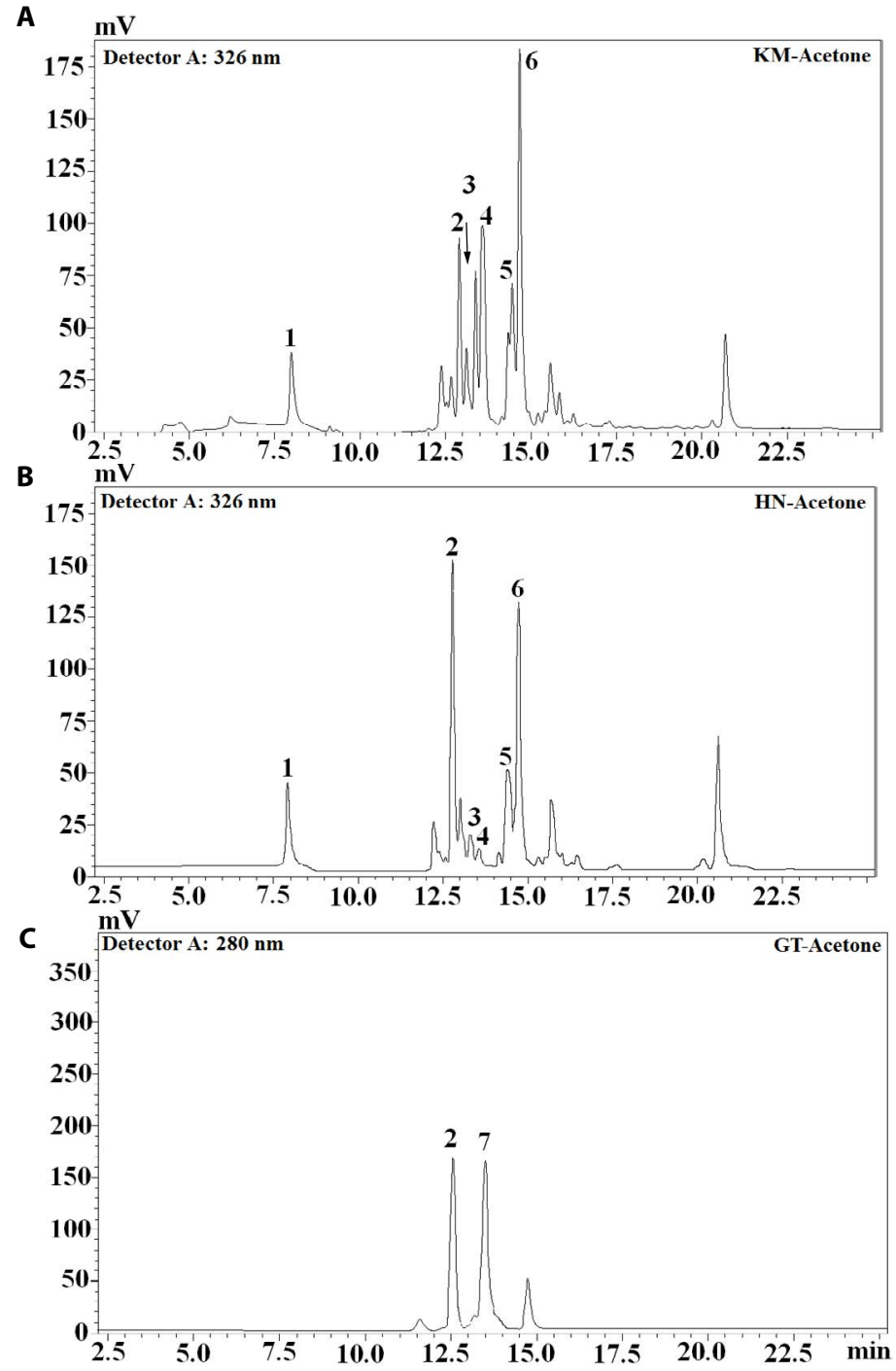

Figure 2. Chromatograms of acetone extracts obtained from jasmine rice leaf and green tea (A: Khao Dok Mali 105 (KM); B: Homnil (HN); C: green tea (GT); 1: Gallic acid; 2: Catechin; 3: 4-Chlorogenic acid; 4: 5-Chlorogenic acid; 5: Caffeic acid; 6: Coumaric acid; 7: Epigallocatechin gallate)

Identification of volatile compounds by gas chromatography mass spectroscopy (GCMS)

Volatile compounds are required in food development as they provide a pleasant scent. Moreover, they exhibit pharmacological activities through their antioxidant, anti-inflammatory, anti-cancer and anti-obesity properties $[21,22]$. Jasmine rice is known for its attractive aroma, therefore the presence of volatile compounds in jasmine rice leaf teas was investigated. The GC-MS profiles of KM, HN and GT volatiles revealed the presence of similar compounds in all teas (Figures 5-7) (Tables 3 and 4). Tridecane was the predominant volatile of KM acetone extract, followed by 2,6-Di-tert-butylphenol and pentadecane. In the KM ethanol extract dominated caryophyllene and 2,6-Di-tertbutylphenol. Five compounds were identified in KM water extract: eicosane, 3-ethyl-5-(2-ethylbutyl) octadecane, etracosane, heneicosane 11-(1-ethylpropyl) and dodecane. Traces of the same compounds were also found in acetone- and ethanol-based extracts (Table 3). Dihydroactiniolide was found in $\mathrm{HN}$ acetone extract, while dodecane isomer and dodecane were detected in ethanol- and water-based extract, respectively (Table 3 ). Three volatile compounds (tridecane, dodecane and 2,6-Di-tert-butylphenol) were found in $\mathrm{HN}$ and $\mathrm{KM}$ water-based extracts. Five volatile compounds, including tridecane, 1-dodecene, dodecane, 1-tetradecene and 2,6-di-tert-butylphenol were identified in GT acetone extract. Green tea ethanol- and water-based extracts comprised, respectively, 3 compounds (tridecane, dodecane, a-fenchylacetate) and 4 compounds (dodecane, 1-tetradecene, 2,6-ditert-butylphenol, eicosane) (Table 4). The results revealed that similar volatile compounds are present in $\mathrm{KM}$ and $\mathrm{HN}$ water-based extracts. This finding suggests that these volatile compounds will be released into tea during the infusion process and may influence its sensory properties and consumers' preferences.

\section{Identification of fatty acid composition}

In a life cell the fatty (carboxylic) acids from foods are utilized in conversion of biochemical energy from nutrients into adenosine triphosphate (ATP). The GCMS analysis of fatty acids revealed the presence of similar fatty acids in all evaluated teas (Table 5). Moreover, similar compounds were detected in all extracts categories (acetone, methanol and water). Acetone extract of KM comprised $\alpha$-linolenic 

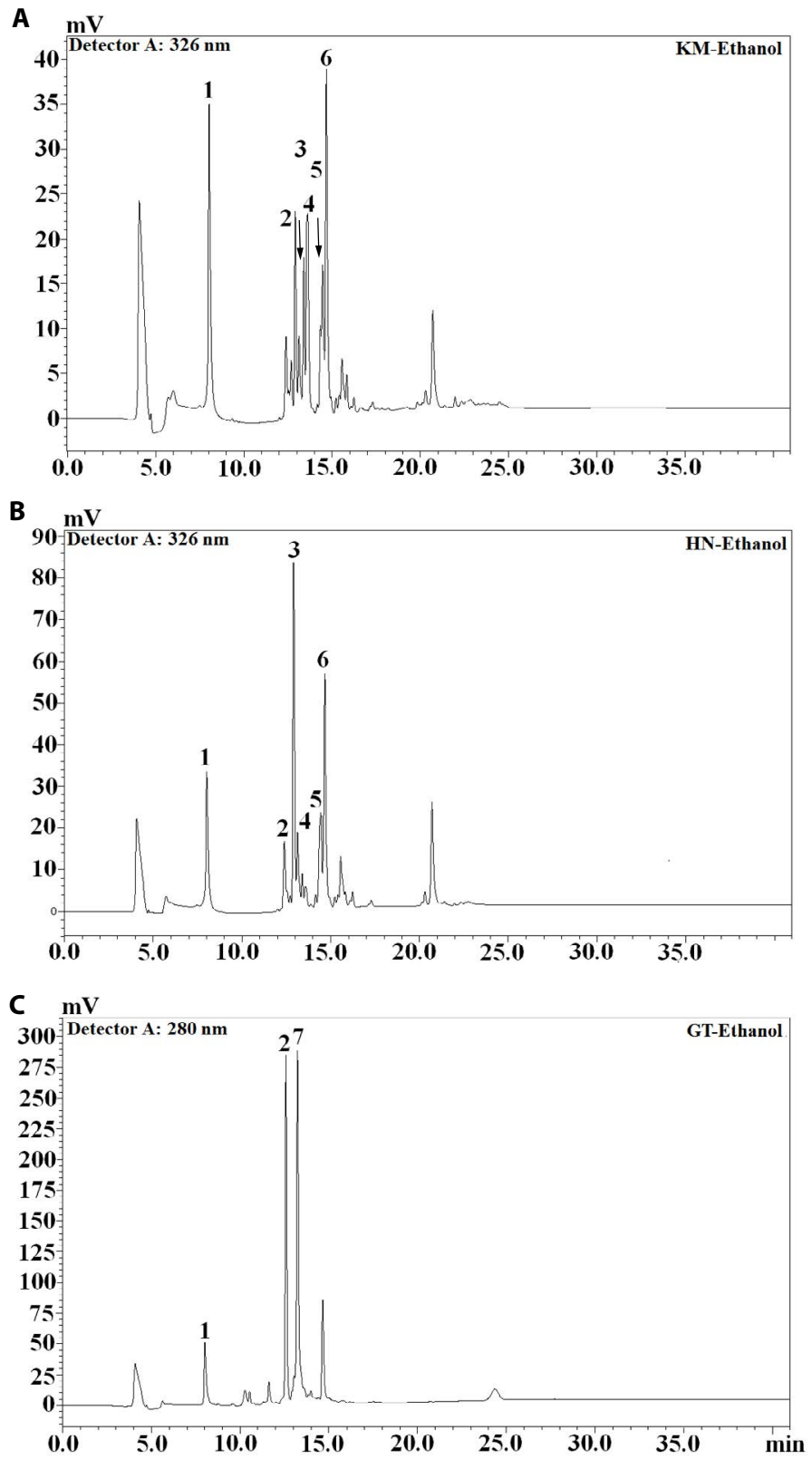

Figure 3. Chromatograms of ethanol extracts obtained from jasmine rice leaf and green tea (A: Khao Dok Mali 105 (KM); B: Homnil (HN); C: green tea (GT); 1: Gallic acid; 2: Catechin; 3: 4-Chlorogenic acid; 4: 5-Chlorogenic acid; 5: Caffeic acid; 6: Coumaric acid; 7: Epigallocatechin gallate)

Table 3. Volatile compounds identified in Khao Dok Mali 105 jasmine rice young leaf tea

\begin{tabular}{|c|c|c|c|c|c|c|c|c|}
\hline \multirow{2}{*}{ No. } & \multirow{2}{*}{$\begin{array}{l}\text { Retention } \\
\text { time }\end{array}$} & \multirow{2}{*}{ Name of compound } & \multirow{2}{*}{$\begin{array}{l}\text { Molecular } \\
\text { formula }\end{array}$} & \multirow{2}{*}{$\begin{array}{l}\text { Molecular } \\
\text { mass }\end{array}$} & \multirow{2}{*}{ Fragment ions } & \multicolumn{3}{|c|}{ Relative concentration (\%) } \\
\hline & & & & & & Acetone & Ethanol & Water \\
\hline 1 & 15.494 & Tridecane & $\mathrm{C}_{13} \mathrm{H}_{28}$ & 184 & $57,71,85,99,127,155$ & 35.91 & ND & ND \\
\hline 2 & 20.169 & Dodecane & $\mathrm{C}_{12} \mathrm{H}_{26}$ & 170 & $57,71,85,99,127,170$ & ND & ND & 5.19 \\
\hline 3 & 21.909 & Pentadecane & $\mathrm{C}_{15} \mathrm{H}_{32}$ & 212 & $57,71,85,99,141,212$ & 3.97 & $\mathrm{~T}$ & $\mathrm{~T}$ \\
\hline 5 & 29.181 & Caryophyllene & $\mathrm{C}_{15} \mathrm{H}_{24}$ & 204 & $55,69,79,93,133,147,189$ & ND & 36.48 & ND \\
\hline 6 & 31.727 & 2,6-Di-tert-butylphenol & $\mathrm{C}_{14} \mathrm{H}_{22} \mathrm{O}$ & 206 & $57,74,91,163,191,206$ & 9.12 & 18.14 & $\mathrm{~T}$ \\
\hline 7 & 37.553 & 3-Ethyl-5-(2-Ethylbutyl) Octadecane & $\mathrm{C}_{26} \mathrm{H}_{54}$ & 366 & $57,71,85,99,183,281$ & ND & ND & 17.30 \\
\hline 8 & 40.219 & Tetracosane & $\mathrm{C}_{24} \mathrm{H}_{50}$ & 338 & $43,57,71,85,99,113,141,155$ & ND & ND & 10.93 \\
\hline 9 & 40.356 & Nonadecane & $\mathrm{C}_{19} \mathrm{H}_{40}$ & 268 & $43,57,71,85,99,113,154$ & $\mathrm{~T}$ & ND & $\mathrm{T}$ \\
\hline 10 & 42.628 & Eicosane & $\mathrm{C}_{20} \mathrm{H}_{42}$ & 282 & $43,57,71,85,99,113,127$ & ND & ND & 17.68 \\
\hline 11 & 45.100 & Heneicosane 11-(1-ethylpropyl) & $\mathrm{C}_{26} \mathrm{H}_{54}$ & 366 & $57,71,85,99,295$ & ND & ND & 6.70 \\
\hline
\end{tabular}

T: Traces; ND: Not detected 
A
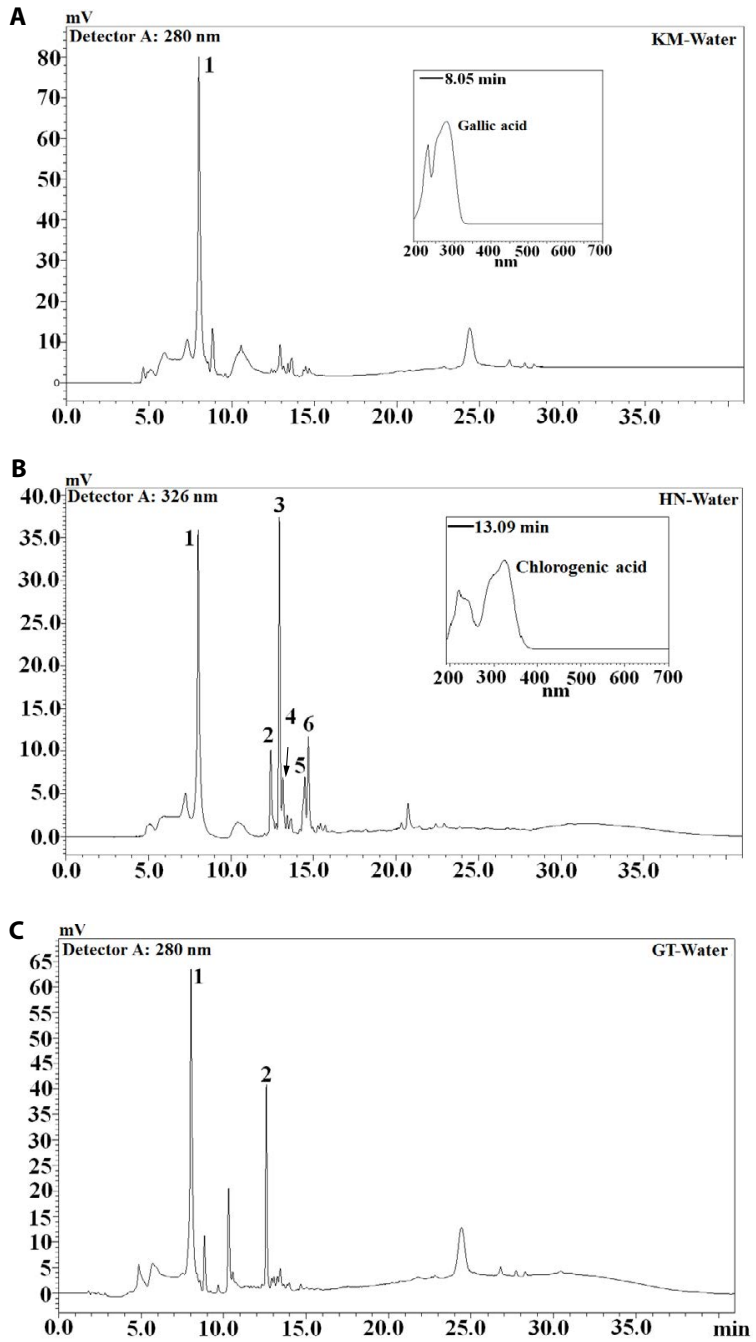

Figure 4. Chromatograms of water extracts obtained from jasmine rice leaf and green tea (A: Khao Dok Mali 105 (KM); B: Homnil (HN); C: greent tea (GT); 1: Gallic acid; 2: Catechin; 3: 4-Chlorogenic acid; 4: 5-Chlorogenic acid; 5: Caffeic acid; 6: Coumaric acid)

Table 4. Volatile compounds identified in Homnil jasmine rice leaf tea and reference sample green tea

\begin{tabular}{|c|c|c|c|c|c|c|c|c|}
\hline \multirow{2}{*}{ No. } & \multirow{2}{*}{$\begin{array}{l}\text { Retention } \\
\text { time }\end{array}$} & \multirow{2}{*}{ Name of compound } & \multirow{2}{*}{$\begin{array}{l}\text { Molecular } \\
\text { formula }\end{array}$} & \multirow{2}{*}{$\begin{array}{l}\text { Molecular } \\
\text { mass }\end{array}$} & \multirow{2}{*}{ Fragment ions } & \multicolumn{3}{|c|}{ Relative concentration (\%) } \\
\hline & & & & & & Acetone & Ethanol & Water \\
\hline \multicolumn{9}{|c|}{ Jasmine rice Homnil } \\
\hline 1 & $15.495,19.883$ & Tridecane & $\mathrm{C}_{13} \mathrm{H}_{28}$ & 184 & $57,71,85,99,127,155$ & ND & ND & 11.17 \\
\hline 2 & 19.883 & Cyclohexasiloxane, dodacamethyl- & $\mathrm{C}_{14} \mathrm{H}_{36} \mathrm{O}_{6} \mathrm{Si}_{6}$ & 444 & $73,117,147,207,341,429$ & ND & ND & 3.02 \\
\hline 3 & 20.175 & Dodecane & $\mathrm{C}_{12} \mathrm{H}_{26}$ & 170 & $57,71,85,99,127,170$ & ND & ND & 23.12 \\
\hline 4 & 20.478 & Cyclohexanone, 4-hydroxy-4-methyl & $\mathrm{C}_{7} \mathrm{H}_{12} \mathrm{O}_{2}$ & 128 & $71,85,95,110,128$ & 28.47 & ND & ND \\
\hline 5 & 21.897 & Dodecane isomer & $\mathrm{C}_{12} \mathrm{H}_{26}$ & 170 & $57,71,85,99,127,170$ & $\mathrm{~T}$ & 21.21 & 8.90 \\
\hline 6 & 24.163 & Cycloheptasiloxane, tetradecamethyl & $\mathrm{C}_{14} \mathrm{H}_{42} \mathrm{O}_{7} \mathrm{Si}_{7}$ & 518 & $73,147,221,281,327,415,503$ & ND & ND & 3.37 \\
\hline 7 & 26.034 & Tetradecane & $\mathrm{C}_{14} \mathrm{H}_{30}$ & 198 & $57,71,85,99,198$ & ND & ND & 11.35 \\
\hline 8 & 31.722 & 2,6-Di-tert-butylphenol & $\mathrm{C}_{14} \mathrm{H}_{22} \mathrm{O}$ & 206 & $57,74,91,163,191,206$ & 10.82 & $\mathrm{~T}$ & $\mathrm{~T}$ \\
\hline 9 & 36.546 & Dihydroactiniolide & $\mathrm{C}_{11} \mathrm{H}_{16} \mathrm{O}_{2}$ & 180 & $67,111,137,180$ & 47.01 & ND & ND \\
\hline \multicolumn{9}{|c|}{ Green Tea } \\
\hline 1 & 15.483 & Tridecane & $\mathrm{C}_{13} \mathrm{H}_{28}$ & 184 & $57,71,85,99,127,155$ & 10.82 & 29.15 & ND \\
\hline 2 & 20.238 & 1-Dodecene & $\mathrm{C}_{12} \mathrm{H}_{24}$ & 168 & $55,69,83,97,168$ & 21.25 & ND & ND \\
\hline 3 & 21.909 & Dodecane & $\mathrm{C}_{12} \mathrm{H}_{26}$ & 170 & $57,71,85,99,127,170$ & 2.61 & 7.78 & 7.01 \\
\hline 4 & 26.109 & 1-Tetradecene & $\mathrm{C}_{14} \mathrm{H}_{28}$ & 196 & $55,69,97,196$ & 20.53 & ND & 9.88 \\
\hline 5 & 28.249 & Alpha-Fenchylacetate & $\mathrm{C}_{12} \mathrm{H}_{20} \mathrm{O}_{2}$ & 196 & $69,80,95,121,136,154,196$ & ND & 5.60 & ND \\
\hline 6 & 31.716 & 2,6-Di-tert-butylphenol & $\mathrm{C}_{14} \mathrm{H}_{22} \mathrm{O}$ & 206 & $57,74,91,163,191,206$ & 12.56 & ND & 3.10 \\
\hline 7 & 42.714 & Eicosane & $\mathrm{C}_{20} \mathrm{H}_{42}$ & 282 & $43,57,71,85,99,113,127$ & ND & ND & 17.89 \\
\hline
\end{tabular}

T: Traces; ND: Not detected 

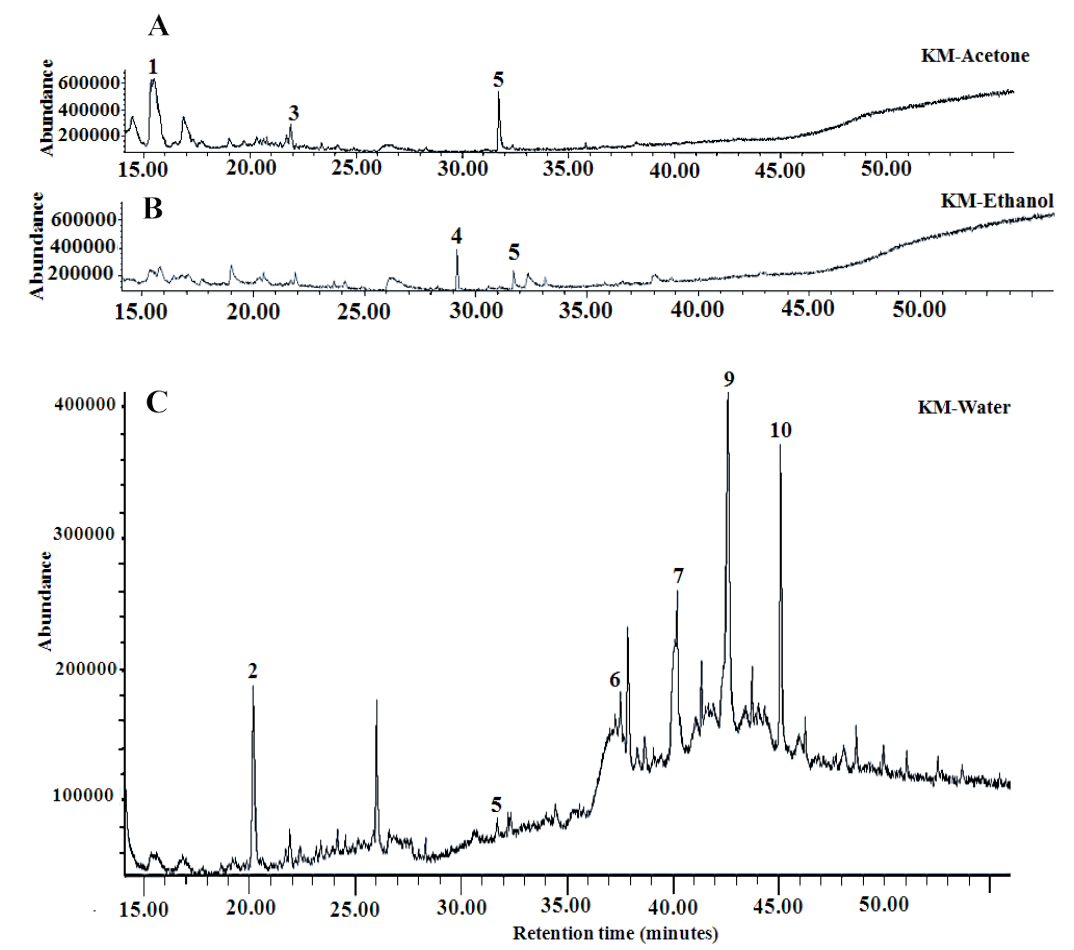

Figure 5. Total ion profile of volatile compounds present in lyophilized sequential extracts obtained from jasmine rice Khao Dok Mali 105 (KM) (A: Acetone; B: Ethanol; C: Water; 1: Tridecane; 2: Dodecane; 3: Pentadecane; 4: Caryophyllene; 5: 2;6-Di-tert-butylphenol; 6: 3-Ethyl-5-(2-Ethylbutyl) Octadecane; 7: Tetracosane; 8: Nonadecane 1; 9: Eicosane; 10: Heneicosane 11-(1-ethylpropyl))
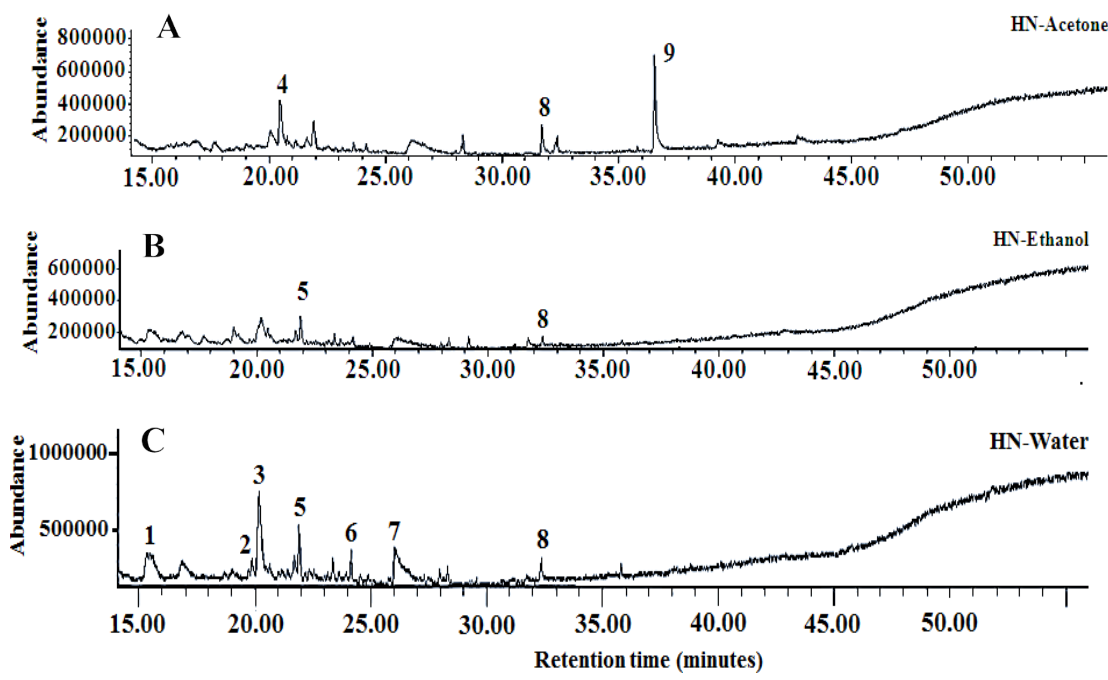

Figure 6. Total ion profile of volatile compounds detected in lyophilized sequential extracts obtained from jasmine rice Homnil (HN) (A: Acetone; B: Ethanol; C: Water; 1: Tridecane; 2: Cyclohexasiloxane; dodacamethyl-; 3: Dodecane; 4: Cyclohexanone; 4-hydroxy-4-methyl; 5: Dodecane isomer; 6: Cycloheptasiloxane; tetradecamethyl; 7: Tetradecane; 8: 2;6-Di-tertbutylphenol 1; 9: Dihydroactiniolide)

acid, palmitic acid and linoleic acid. The fatty acids compositions of ethanol- and water-based extracts of KM and HN were comparable (Table 3). The ethanol-based KM and HN extracts also contained a-linolenic acid, palmitic acid and linoleic acid. Traces of stearic acid were also present. The water extracts contained $\alpha$-linolenic acid, palmitic acid and linoleic acid. Similar fatty acids composition and content was found in GT extracts with the exception of vaccenic acid which was detected in acetone and ethanol extracts and stearic acid detected in water extract. According to Kobayashi and collaborators
[23], presence of the major fatty acid derivatives: C6 and C9 alcohols and aldehydes in green tea is the key contributor to its fresh odor.

\section{Enzyme inhibitory activities}

Obesity - one of the greatest threats to global health is currently treated with synthetic inhibitors of digestive enzymes, such as acarbose and orlistat. Because an uptake of synthetic inhibitors may lead to unwanted side effects, the attention of researchers is directed to natural compounds from plant sources that provide safer alternative. Within 


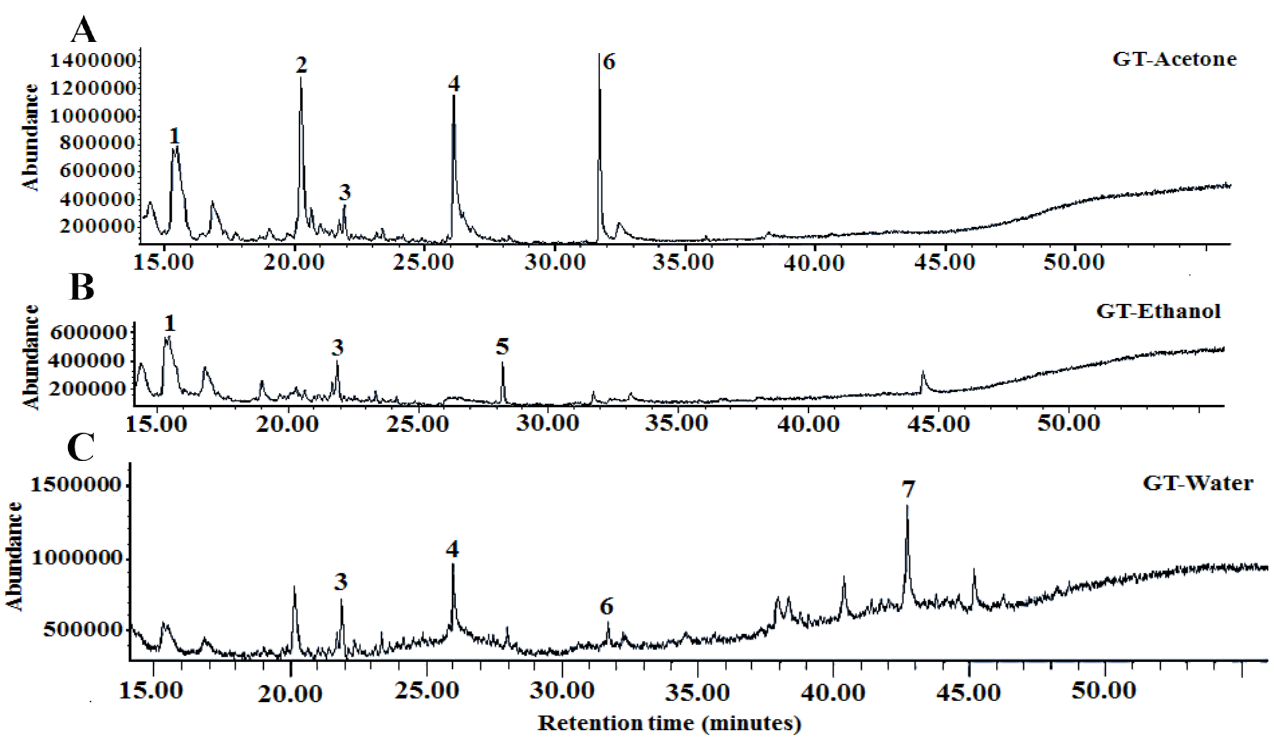

Figure 7. Total ion profile of volatile compounds presents in lyophilized sequential extracts obtained from green tea (GT) (A: Acetone; B: Ethanol; C: Water; 1: Tridecane; 2: 1-Dodecene; 3: Odecane; 4: 1-Tetradecene; 5: Alpha-Fenchylacetate; 6: 2;6-Di-tert-butylphenol; 7: Eicosane)

Table 5. Fatty acid composition identified acetone, ethanol and water-based extracts of jasmine rice young leaf tea, cultivars Khao Dok Mali 105 (KM) and Homnil (HN) and reference sample green tea (GT)

\begin{tabular}{|c|c|c|c|}
\hline Compounds & Acetone (A) & Ethanol (E) & Water (W) \\
\hline \multicolumn{4}{|c|}{$K M$} \\
\hline Palmitic acid & 21.10 & 25.53 & 27.17 \\
\hline Stearic acid & $\mathrm{T}$ & 2.52 & $\mathrm{~T}$ \\
\hline Vaccenic acid & ND & ND & ND \\
\hline Linoleic acid & 16.6 & 21.33 & 22.66 \\
\hline$\alpha$-Linolenic acid & 56.74 & 47.62 & 44.73 \\
\hline \multicolumn{4}{|c|}{$H N$} \\
\hline Palmitic acid & 21.81 & 25.39 & 26.90 \\
\hline Stearic acid & $\mathrm{T}$ & $\mathrm{T}$ & 4.02 \\
\hline Vaccenic acid & ND & ND & ND \\
\hline Linoleic acid & 15.97 & 19.70 & 19.43 \\
\hline$\alpha$-Linolenic acid & 57.79 & 49.37 & 46.11 \\
\hline \multicolumn{4}{|c|}{$G T$} \\
\hline Palmitic acid & 24.11 & 29.63 & 33.13 \\
\hline Stearic acid & $\mathrm{T}$ & $\mathrm{T}$ & 23.92 \\
\hline Vaccenic acid & 6.72 & 9.38 & $\mathrm{~T}$ \\
\hline Linoleic acid & 17.76 & 21.97 & 7.64 \\
\hline$\alpha$-Linolenic acid & 45.12 & 33.99 & 20.12 \\
\hline
\end{tabular}

this study enzyme-inhibitory activities of jasmine rice leaf teas were evaluated.

\section{Alpha-amylase and pancreatic lipase inhibitory activities}

The extracts of KM and HN tea inhibited the activity of $\alpha$-amylase in a dose response manner (data not shown). The inhibitory activity of KM acetone extract was 2.3-fold that of KM ethanol- and 9.8-fold that of KM water-based extract. The acetone and ethanol extracts of HN exhibited comparable $\alpha$-amylase inhibitory activities and were 6.6-fold those of $\mathrm{HN}$ water extract. Alpha-amylase inhibitory activities of water extracts obtained from all evaluated samples were comparable (Table 6).

Acetone extract of KM as well as acetone extract of GT exhibited the strongest and similar pancreatic lipase inhibition. The inhibitory activity of $\mathrm{HN}$ acetone extract was 3.5-fold lower (Table 6). Similar low inhibitory activities towards pancreatic lipase showed ethanol and water extracts of $\mathrm{KN}$ and $\mathrm{HN}$. Lipase inhibitory activities of jasmine rice leaf teas were lower than those of Eremochloa ophiuroides (centipede grass) leaf methanolic extracts $\left(\mathrm{IC}_{50}\right.$ of $33.6 \pm 2.0 \mu \mathrm{M}$ equal to $0.019 \pm 0.001 \mathrm{mg} /$ $\mathrm{mL}$ ) [24].

Chlorogenic acid possesses pronounced $\alpha$-amylase inhibitory properties [24]. The presence of chlorogenic acid at high levels in ethanol- and acetone-based extracts of jasmine rice leaf teas may be responsible for the enzyme inhibition observed in this study. Lower levels of chlorogenic acid in $\mathrm{KM}$ and $\mathrm{HN}$ water-based extracts correlate well with the lower $\mathrm{IC}_{50}$ values (Table 6). Structure of dietary polyphenols influences their $\alpha$-amylase inhibitory effect (Xiao et al., 2013). This effect increases with the presence of hydroxylation of flavonoids and/or presence of an unsaturated 2,3-bond in conjugation with a 4-carbonyl group. Glycosylation of flavonoids as well as methylation and methoxylation weakens the inhibitory effect $[25,26]$. In agreement, in the present study the chlorogenic acid rich extracts obtained from KM and $\mathrm{HN}$ rice teas exhibited pronounced enzyme-inhibitory activities. 
Table 6. Enzyme $\alpha$-amylase and pancreatic lipase inhibitory activities of acetone, ethanol and water-based extracts of jasmine rice young leaf tea, cultivars Khao Dok Mali 105 (KM) and Homnil (HN) and reference sample green tea (GT)

\begin{tabular}{|c|c|c|c|c|}
\hline \multicolumn{2}{|c|}{ Tea sample inhibitory activity samples } & \multirow[t]{2}{*}{ Acetone (A) } & \multirow[t]{2}{*}{ Ethanol (E) } & \multirow[t]{2}{*}{ Water $(\mathrm{W})$} \\
\hline KM & & & & \\
\hline & $\alpha$-amylase $\left(\mathrm{IC}_{50} ; \mu \mathrm{g} / \mathrm{mL}\right)$ & $73.96 \pm 2.7^{\mathrm{a}}$ & $168.65 \pm 19.2^{\mathrm{b}}$ & $724.99 \pm 21.3^{\mathrm{c}}$ \\
\hline & Acarbose E. $(\mu \mathrm{M} / \mathrm{g}$ extract $)$ & $656.22 \pm 48.0^{\mathrm{a}}$ & $288.87 \pm 32.8^{\mathrm{b}}$ & $66.85 \pm 2.03^{\mathrm{c}}$ \\
\hline & Pancreatic lipase $\left.\left(\mathrm{IC}_{50}\right) \mu \mathrm{g} / \mathrm{mL}\right)$ & $65.7 \pm 5.8^{\mathrm{a}}$ & $329.6 \pm 0.7^{\mathrm{b}}$ & $870.9 \pm 33.6^{\mathrm{c}}$ \\
\hline & Orlistat E. $(\mu \mathrm{M} / \mathrm{g}$ extract $)$ & $42.2 \pm 3.9^{\mathrm{a}}$ & $8.4 \pm 0.0^{\mathrm{b}}$ & $3.2 \pm 0.1^{\mathrm{c}}$ \\
\hline \multicolumn{5}{|l|}{$H N$} \\
\hline & $\alpha$-amylase $\left(\mathrm{IC}_{50} ; \mu \mathrm{g} / \mathrm{mL}\right)$ & $113.6 \pm 7.07^{\mathrm{a}}$ & $116.2 \pm 0.05^{\mathrm{a}}$ & $752.48 \pm 0.67^{\mathrm{b}}$ \\
\hline & Acarbose E. $(\mu \mathrm{M} / \mathrm{g}$ extract $)$ & $426.92 \pm 26.6^{\mathrm{a}}$ & $415.15 \pm 2.01^{\mathrm{a}}$ & $64.32 \pm 0.06^{\mathrm{b}}$ \\
\hline & Pancreatic lipase $\left.\left(\mathrm{IC}_{50}\right) \mu \mathrm{g} / \mathrm{mL}\right)$ & $227.0 \pm 1.4^{\mathrm{a}}$ & $353.8 \pm 5.1^{\mathrm{b}}$ & $821.0 \pm 14.9^{\mathrm{c}}$ \\
\hline & Orlistat E. $(\mu \mathrm{M} / \mathrm{g}$ extract $)$ & $12.2 \pm 0.1^{\mathrm{a}}$ & $7.8 \pm 0.1^{\mathrm{b}}$ & $3.4 \pm 0.1^{\mathrm{c}}$ \\
\hline \multicolumn{5}{|l|}{$G T$} \\
\hline & $\alpha$-amylase $\left(\mathrm{IC}_{50} ; \mu \mathrm{g} / \mathrm{ml}\right)$ & $93.86 \pm 2.54^{\mathrm{a}}$ & $102.4 \pm 0.79^{\mathrm{b}}$ & $700.02 \pm 5.18^{c}$ \\
\hline & Acarbose E. $(\mu \mathrm{M} / \mathrm{g}$ extract $)$ & $515.92 \pm 13.95^{\mathrm{a}}$ & $472.48 \pm 3.59^{\mathrm{b}}$ & $69.51 \pm 0.02^{\mathrm{c}}$ \\
\hline & Pancreatic lipase $\left.\left(\mathrm{IC}_{50}\right) \mu \mathrm{g} / \mathrm{mL}\right)$ & $63.3 \pm 1.2^{\mathrm{c}}$ & $147.4 \pm 3.3^{\mathrm{b}}$ & $788.9 \pm 6.9^{\mathrm{a}}$ \\
\hline & Orlistat E. $(\mu \mathrm{M} / \mathrm{g}$ extract $)$ & $43.6 \pm 0.8^{\mathrm{a}}$ & $18.7 \pm 0.4^{\mathrm{b}}$ & $3.5 \pm 0.0^{c}$ \\
\hline
\end{tabular}

These activities are comparable to those of commonly used medicinal plant teas utilized in Turkey [11].

\section{Conclusions}

Acetone- and ethanol-based extracts of jasmine rice leaf contained predominantly chlorogenic acid, accompanied by other hydroxycinnamic ( $p$-coumaric acid, caffeic acid) and phenolic acids (gallic acid). The acetone-based extract of $\mathrm{KM}$ and ethanol-based extract of $\mathrm{HN}$ contained predominantly chlorogenic acid and exhibited comparable $\alpha$-amylase inhibitory activities. This study indicates that jasmine rice leaf tea extract may modulate the metabolism of sugars and fats through inhibition of the relevant digestive enzymes. Young jasmine rice leaf can be utilized as an alternate plant source for the production of a novel functional tea.

\section{Acknowledgements}

Authors acknowledged the Faculty of Agriculture and Technology, Rajamangala University of Technology Isan (RMUTI), Surin campus, Thailand and Faculty of Pharmacy, Van Yuzuncu Yil University, Turkey, for providing necessary facilities and financial support to carry out this research.

\section{Conflicts of interest}

The Authors declare no conflict of interest in carrying out this research or preparing this article for publication.

\section{References}

1. Sur S, Panda CK (2017) Molecular aspects of cancer chemo preventive and therapeutic efficacies of tea and tea polyphenols. Nutr 43-44: 8-15. [Crossref]

2. Senanayake SPJN (2013) Green tea extract: Chemistry, antioxidant properties and food application - A review. J Funct Foods 5: 1529-1541.

3. Oh J, Jo H, Cho AR, Kim SJ, Han J (2013) Antioxidant and antimicrobial activities of various leafy herbal teas. Food Control 31: 403-409.

4. Qi G, Mi Y, Liu Z, Fan R, Qiao Q, et al. (2017) Dietary tea polyphenols ameliorate metabolic syndrome and memory impairment via circadian clock related mechanisms. J Funct Foods 34: 168-180.

5. Rashidi B, Malekzadeh M, Goodarzi M, Masoudifar A, Mirzaei H (2017) Green tea and its anti-angiogenesis effects. Biomed Pharmacother 89: 949-956. [Crossref]
6. Rahmani AH, Al shabrmi FM, Allemailem KS, Aly SM, Khan MA (2015) Implications of green tea and its constituents in the prevention of cancer via the modulation of cell signalling pathway. BioMed Res Intern.

7. Deetae P, Parichanon P, Trakunleewatthana P, Chanseetis C, Lertsiri S (2012) Antioxidant and anti-glycation properties of Thai herbal teas in comparison to conventional teas. Food Chem 133: 953-959.

8. Yin DD, Yuan RY, Wu Q, Li SS, Shao S, et al. (2015) Assessment of flavonoids and volatile compounds in tea infusions of water lily flowers and their antioxidant activities. Food Chem 187: 20-28. [Crossref]

9. Orthoefer FT (2005) Rice brain oil. In: Shahidi F (Ed.), Bailey's industrial oil and fat products. John Wiley \& Sons Inc, New York, pp: 465-487.

10. Rice in Thailand: Agriculture, history what makes jasmine rice so special. Thailand foreign office, The government public relations department. Retrieved on January 10 2018. http://factsanddetails.com/southeast-asia/Thailand/sub5_8h/entry-3321.html

11. Dalar A, Türker M, Zabaras D, Konczak I (2014) Phenolic composition, antioxidant and enzyme inhibitory activities of eryngium bornmuelleri leaf. Plant Foods Hum Nutr 69: 30-36. [Crossref]

12. Sakulnarmrat K, Konczak I (2012) Composition of native Australian herbs polyphenolic-rich fractions and in vitro inhibitory activities against key enzymes relevant to metabolic syndrome. Food Chem 34: 1011-1019. [Crossref]

13. Sharma OP, Bhat TK (2009) DPPH antioxidant assay revisited. Food Chem 113: 1202 1205 .

14. Official method of analysis of AOAC international. 17th Edition. AOAC International, Maryland, USA.

15. Dalar A, Konczak I (2013) Phenolic contents, antioxidant capacities and inhibitory activities against key metabolic syndrome relevant enzymes of herbal teas from Eastern Anatolia. Ind Crops Prod 44: 383-390.

16. Dalar A, Konczak I (2012) Botanicals from Eastern Anatolia region of Turkey antioxidant capacity and phenolic constituents of endemic herbal medicines. $J$ Herb Med 2: 126-135.

17. Verzera A, Ziino M, Condurso C, Romeo V, Zappalà M (2004) Solid-phase microextraction and gas chromatography-mass spectrometry for rapid characterisation of semi-hard cheeses. Anal Bioanal Chem 380: 930-936. [Crossref]

18. Dool van den H, Kratz PD (1963) A generalization of the retention index system including linear temperature programmed gas-liquid partition chromatography. $J$ Chromatogr A 11: 463-471.

19. Uzun Y, Dalar A, Konczak I (2017) Sempervivum davisii: phytochemical composition, antioxidant and lipase-inhibitory activities. Pharmaceut Biol 55: 532-540. [Crossref] 
20. Dai J, Mumper RJ (2010) Plant phenolics: extraction, analysis and their antioxidant and anticancer properties. Molecules 15: 7313-7352. [Crossref]

21. Ayseli MT, Ayseli Yİ (2016) Flavors of the future: health benefits of flavor precursors and volatile compounds in plant foods. Trends Food Sci Technol 48: 69-77.

22. Schwab W, Davidovich-Rikanati R, Lewinsohn E (2008) Biosynthesis of plant derived flavor compounds. Plant J 54: 712-732. [Crossref]

23. Kobayashi A, Kawamura M, Yamamoto Y, Shimizu K, Kubota K, et al. (1988) Methyl epijasmonate in the essential oil of tea. Agric Biol Chem 52: 2299-2303.
24. Lee EM, Lee SS, Chung BY, Cho JY, Lee IC, et al. (2010) Pancreatic lipase inhibition by $\mathrm{C}$-glycosidic flavones Isolated from Eremochloa ophiuroides. Molecules 15: 82518259. [Crossref]

25. Xiao J, Ni X, Kai G, Chen X (2013) A review on structure-activity relationship of dietary polyphenols inhibiting $\alpha$-amylase. Crit Rev Food Sci Nutr 53: 497-506. [Crossref]

26. Narita Y, Inoue K (2009) Kinetic analysis and mechanism on the inhibition of chlorogenic acid and its components against porcine pancrease alpha-amylase isozymes I and II. J Agric Food Chem 57: 9218-9225. [Crossref]

Copyright: (C2018 Sakulnarmrat K. This is an open-access article distributed under the terms of the Creative Commons Attribution License, which permits unrestricted use, distribution, and reproduction in any medium, provided the original author and source are credited. 